\title{
PELAKSANAAN PENGEMBANGAN PENDIDIKAN KEWARGANEGARAAN YANG IDEAL BAGI PELAJAR SEKOLAH MENENGAH
}

\author{
Ramadani Harni \\ Universitas Negeri Padang, Padang \\ ramadaniharni10@gmail.com
}

\begin{abstract}
Abstrak
Tujuan penelitian ini yaitu untuk mengetahui tingkat dari profesionalisme guru PKn, upaya dalam pengembangan profesionalisme guru PKn dan untuk menganalisis kendalakendala yang menghambat upaya dalam pengembangan profesionalisme guru PKn dalam proses pembelajarannya. Penelitian ini merupakan penelitian merupakan penelitian mix methods, yang mana penelitian ini merupakan penelitian campuran yang mengkombinasikan anatara penelitian kuantitatif dengan penelitian kualitatif. Hasil penelitian menunjukkan bahwa (1) tingkatan profesionalisme guru PKn dapat dikatakan belum sepenuhnya mampu dalam menguasai beberpa kompetensi yang harus dimiliki. Terutama yang berhubungan dengan pembelajaran, ini disebabkan kebanyakan guru yang mengajar masih tidak sesuai dengan bidang studinya. (2) upaya dalam peningkatan profesionalisme guru PKn dalam proses pengembangannya telah dilakukan oleh tiga pihak yaitu Dinas Pendidikan, Kepala Sekolah, dan guru-guru PKn di Kecamatan Singingi. Dinas pendidikan telah mengadakan workshop dan seminar- seminar, serta kegiatan-kegiatan yang lainnya dalam pengembangan profesionalisme guru.
\end{abstract}

Kata kunci : Kompetensi; Kewarganegaraan; Pancasila. 


\title{
IMPLEMENTATION OF THE IDEAL CITIZENSHIP EDUCATION DEVELOPMENT FOR HIGH SCHOOL STUDENTS
}

\begin{abstract}
The purpose of this study is to determine the level of professionalism of Civics teachers, efforts in developing Civics teacher professionalism and to analyze the obstacles that hinder efforts in developing Civics teacher professionalism in the learning process. This research is a mixed methods research, which is a mixed research that combines quantitative research with qualitative research. The results of the study indicate that (1) the level of professionalism of Civics teachers can be said to have not been fully capable of mastering several competencies that must be possessed. Especially those related to learning, this is because most teachers who teach are still not in accordance with their field of study. (2) efforts to increase the professionalism of Civics teachers in the development process have been carried out by three parties, namely the Education Office, Principals, and Civics teachers in Singingi District. The education office has held workshops and seminars, as well as other activities in the development of teacher professionalism.
\end{abstract}

Keywords: Competence; Citizenship; Pancasila. 
e-ISSN : 2621-4105

\section{A. PENDAHULUAN}

Guru merupakan komponen yang paling menentukan dalam system pendidikan. Sesuai dengan amanat dalam konstitusi Negara Indonesia yang tercantum dalam Pembukaan Undang-Undang Dasar 1945 mrnyatakan bahwa salah satu tujuan Negara republik Indonesia adalah mencerdaskan kehidupan bangsa dan untuk itu setiap warga Negara Indonesia berhak memperoleh pendidikan yang bermutu. Untuk mewujudkan pendidikan yang bermutu maka guru merupaka salah satu mesin dalam mengsukseskan pendidikan nasional. Mengajar maupun mendidik merupakan tugas dan tanggung jawab guru sebagai tenaga profesional. Karena dapat dikatakan seorang guru merupakan komponen yang paling menentukan dalam system pendidikan, karena pekerjaan guru adalah pekerjaan yang profesional, maka seorang guru harus profesionalisme. Menurut Hamni Fadillah Nasution, profesionalisme guru adalah guru yang bisa menguasai dan memeriksa perubahan yang terjadi di dalam pengetahuan dan teknologi. Yang mana profesionalisme guru dimaknai sebagai mutu, kualitas, dan tindak tanduk yang merupaka curi suatu profesi atau orang yang profesional. Untuk memenuhi guru profesionalisme itu harus memiliki empat kompetensi yang menjadi persyaratan sesorang guru profesionalisme yaitu; kompetensi pedagogik. Kompetensi profesional, kompetensi kepribadian, dan kompetensi sosial. ${ }^{1}$

Kompetensi pedagogik adalah adalah kompetensi yang berhubungan dengan tugastugas pendidikan dan keguruan. Kompetensi kepribadian meliputi sikap yang positif terhadap keseluruhan tugasnya sebagai guru dan terhadap keseluruhan situasi pendidikan beserta unsur-unsurnya. Kompetensi profesional adalah kemampuan guru dalam penguasaan materi pelajaran secara luas dan mendalam yang memungkinkan membimbing peserta didik memenuhi kompetensi yang ditetapkan. Dan kompetensi sosial adalah kemampuan guru sebagai bagian dari masyarakat dalam berkomunikasi dan bergaul secara efektif dengan peserta didik dan masyarakat sekitar.

Penelitian sebelumnya yang mengakaji tentang pengembangan pendidikan kewarganegaraan diteliti oleh Sri Wahyuni Tanshzil yang berjudul "Model Pembinaan Pendidikan Karakter Pada Lingkungan Pondok Pesantren Dalam Membangun Kemandirian Dan Disiplin Santri” (Sebuah kajian pengembangan Pendidikan

\footnotetext{
${ }^{1}$ Fadlillah Hamni Nasution, “Urgensi Profesionalisme Guru di Pendidikan Sekolah Dasar”, Jurnal Ar Riayah : Jurnal Pendidikan Dasar 1 (1), 2017, hal 1-22. DOI: http://dx.doi.org/10.29240/jpd.v1i1.218
} 
e-ISSN : 2621-4105

Kewarganegaraan). Penelitian ini mengkaji bagaimana model pembinaan pendidikan karkater pada lingkungan pondok pesantren dalam membangun kemandirian dan disiplin santri. Pendekatan yang digunakan adalah kualitatif dengan metode studi kasus, untuk mengungkapkan dan memahami kenyataan-kenyataan yang terjadi mendalam yang berkenaan dengan fenomena di atas. Hasil dari penelitian ini menyebutkan bahwa proses pembinaan pendidikan karkater dalam membangun kemandirian dan disiplin santri di lingkungan Pondok Pesantren KH. Zainal Mustafa dilaksanakan dengan pendekatan menyeluruh, melalui pembelajaran, kegiatan ekstrakulikuler, pembiasaan, serta kerjasama dengan masyarakat dan keluarga, dan membangun kedisiplinan dan kemandirian santri. ${ }^{2}$

Penelitian oleh Sri Haryati (2018) dengan judul "Konstruksi Isu Aktual Bidang Ketahanan Nasional Untuk Pengembangan Isi Pendidikan Kewarganegaraan Persekolahan". Penelitian tersebut mengkonstruksi isu aktual bidang ketahanan nasional dalam pengembangan isi pendidikan kewarganegaraan persekolahan berupa deskripsi pengetahuan tentang isu aktual kewarganegaraan bidang ketahanan nasional sebagai isi pendidikan kewarganegaraan persekolahan. Penelitian menggunakan pendekatan deskriptif kualitatif. Sumber data informan dengan teknik purposive sampling, dokumen dan kepustakaan yang relevan. Data dikumpulkan dan diolah dengan cara wawancara mendalam, FGD, observasi, dan studi dokumen. Validitas data dilakukan melalui proses trianggulasi sumber dan metode. Data dianalisis melalui reduksi data, pemyajian data, dan penarikan kesimpulan. Penelitian ini menemukan rumusan tentang deskripsi isi pendidikan kewarganegaraan berdasarkan isu aktual bidang ketahanan nasional yaitu tentang isu-isu ipoleksosbudhankam berupa kajian kompetensi dasar yang diterjemahkan menjadi indikator-indikator untuk mencapai tujuan dari kompetensi dasar tersebut. ${ }^{3}$

Heri Hidayat (2020) dalam penelitiannya yang berjudul "Peranan Teknologi Dan Media Pembelajaran Bagi Siswa Sekolah Dasar Di Dalam Pembelajaran Pendidikan Kewarganegaraan" lebih banyak mengkaji tentang pengembangan pendidikan kewarganegaraan dengan menggunakan teknologi digital. Dalam penelitinanny atersebut

\footnotetext{
${ }^{2}$ Sri Wahyuni Tanshzil, "Model Pembinaan Pendidikan Karakter Pada Lingkungan Pondok Pesantren Dalam Membangun Kemandirian Dan Disiplin Santri (Sebuah kajian pengembangan Pendidikan Kewarganegaraan) ' Jurnal Pendidikan Penelitian 12 (2), 2012.

${ }^{3}$ Sri Haryati, "Konstruksi Isu Aktual Bidang Ketahanan Nasional Untuk Pengembangan Isi Pendidikan Kewarganegaraan Persekolahan”, Jurnal Ketahanan Nasional 24 (3), 2018, hal 342-353. https://doi.org/10.22146/jkn.35490
} 
e-ISSN : 2621-4105

pengembangan pendidikan Kewarganegaraan dilaksanakan dengan menggunakan alat teknologi seperti proyektor, audio visual, pengembangan game education agar dapat memudahkan para siswa dalam menyerap dan menerima materi pembelajaran Kewarganegaraan, mengingat pendidikan Kewarganegaraan sangat penting dalam menannamkan nilai-nilai ideologi Pancasila. ${ }^{4}$

Perbedaan penelitian ini dengan penelitian sebelumnya adalah, penelitian ini menganalisis pengembangan profesionalisme pendidik kewarganegaan yang merupakan saarana dalam menanamkan nilai-nilai Pancasila. Penelitian ini juga menganalisis kendala-kendala yang menghambat upaya dalam pengembangan profesionalisme pendidik di bidang Kewarganegaraan. Perbedaan selanjutnya adalah lokasi penelitian ini dilakukan di Sekolah Menengah pertama Negeri yang berada di Kecamatan Singingi Kabupaten Kuantan yang mana terdapat 7 SMP negeri. Perbedaan penelitian tersebut sekaligus sebagai tujuan dalam penelitian ini.

\section{B. PERMASALAHAN}

Dari uraian pendahulaun tersebut diatas maka peramsalahan yang diangkat di penelitian ini adalah bagaimanakah pengembangan pembelajaran pendidikan kewarganegaraan yang ideal bagi pelajar sekolah menengah?

\section{METODE PENELITIAN}

Penelitian ini menggunakan metode penelitian mix methods. Menurut Creswel penelitian Mix Methods yaitu, suatu langkah penelitian dengan menggabungkan dua bentuk pendekatan penelitian, yaitu penelitian kualitatif dan penelitian kuantitatif. 5 Sedangkan menurut Sugiyono metode penelitian dengan mengkombinasikan antara dua motode penelitian sekaligus. ${ }^{6}$ Metode dalam penelitian ini menggunakan metode campuran beruntun yang mana waktu penelitiannya sejajar atau bersamaan untuk mengumpulkan data kualitatif atau data kuantitatif dan dikumpulkan dalam waktu bersamaan. Penentuan lokasi penelitian ini dilakukan di Sekolah Menengah pertama Negeri yang berada di Kecamatan Singingi yang mana terdapat 7 SMP negeri .

\footnotetext{
${ }^{4}$ Heri Hidayat, Heny Mulyani, Sri Devi Nurhasanah, Wilma Khairunnisa, Zakitush Sholihah, "Peranan Teknologi Dan Media Pembelajaran Bagi Siswa Sekolah Dasar Di Dalam Pembelajaran Pendidikan Kewarganegaraan”, Jurnal Pendidikan Kewarganegaraan 8 (2) 2020, hal 57-65.

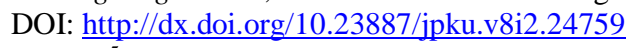

${ }^{5}$ Creswel, J, W. (2010), “Reseach Design : Pendekatan Kualitatif, Kuantitatif, dan Mixed", Yogyakarta: PT Pustaka Pelajar.

6 Sugiyono Sugiyono, (2010), "Metodologi Penelitian Pendidikan Kualitatif, Pendekatan Kuantitatif, Kualitatif, dan R\&D”, Bandung: Alfabeta.
} 
Penelitian ini mengambil populasi seluruh guru PPKn yang mengajar di SMPN Kec. Singingi.teknik pengambilan data dalam penelitian ini menggunakan tekni "Total Sampling". Menurut Sugiyono, Total Sampling adalah "teknik pengambilan sampel dimana jumlah sampel sama dengan populasi". ${ }^{7}$ Populasi dalam penlitian ini adalah guru PKn yang berjumlah 15 orang guru. Sedangkan informan dalam penelitian ini yaitu 15 orang guru PPKn, 7 orang kepala sekolah, dan kepela Dinas Pendidikan.

Teknik pengumpulan data dilakukan dengan data kuanitatif dan kualitatif. Data kuanitatif menggunakan kuesioner (angket) dan data kualitatif dengan menggunakan observasi, wawancara, dan dokumentasi. Untuk menguji keabshan data, peneliti menggunakan triangunilasi sumber dan triangunilasi metod. Menurut Sutopo triangunilasi sumber merupakan cara yang mengarahkan peneliti agar dalam mengumpulkan data, penelitian ini wajib menggunakan beragam sumber data yang tersedia. ${ }^{8}$ Artinya, data yang sama atau sejenis akan lebih mantap kebenarannya aapabila digali dari beberapasumber yang berbeda, sedangkan triangunilasi metode merupakan cara yang dilakukan peneliti untuk mengumpulkan data dengan menggunakan metode yang berbeda dengan tujuan untuk menguji kemantapan informasinya.

Dalam analisis data penelitian ini menggunakan dua teknik yaitu untuk data kuantitatifnya dengan menggunakan teknik persentasi yang menggunakan skala likert. Dan untuk analisis data kualitatifnya dengan menggunakan teknik analisis interaktif. Artinya dalam pengumpulan data peneliti membuat reduksi data dan sajian data. Setelah semua data terkumpul peneliti menarik simpulan berdasarkan reduksi data dan sajian data yang telah di buat. Teknik pengumpulan data dalam penelitian ini adalah observasi, angket, wawancara, mendalam, studi dokumentasi, dan kepustakaan.

\section{HASIL DAN PEMBAHASAN}

\section{Pengembangan Pembelajaran Pendidikan Kewarganegaraan Yang Ideal Bagi Pelajar Sekolah Menengah}

Membina moral yang diharapkan dapat diwujudkan dalam kehidupan sehari-hari, yaitu perilaku yang memancarkan iman dan takwa terhadap Tuhan Yang Maha Esa dalam masyarakat yang terdiri dari berbagai golongan agama, perilaku yang bersifat kemanusiaan yang adil dan beradab, perilaku yang mendukung persatuan bangsa dalam masyarakat yang beraneka ragam kepentingan, perilaku yang mendukung kerakyatan

\footnotetext{
${ }^{7}$ Ibid.

${ }^{8}$ H. B. Sutopo, (2002), “Pengantar Penelitian Kualitatif”, Surakarta : Universitas Sebelas Maret Press.
} 
e-ISSN : 2621-4105

yang mengutamakan kepentingan bersama di atas kepentingan perorangan dan golongan sehingga perbedaan pemikiran, pendapatan, ataupun kepentingan di atas melalui musyawarah dan mufakat, serta perilaku yang mendukung upaya untuk mewujudkan keadilan sosial bagi seluruh rakyat Indonesia. ${ }^{9}$

Guru yang profesional pada dasarnya sesuai dengan pasal 10 Undang-Undang No 14 Tahun 2005 tentang guru dan dosen yaitu memiliki kompetensi pedagogik, kompetensi kepribadian, kompetensi sosial, dan kompetensi profesiona yang diperoleh melalui pendidikan profesi. Disini peneliti hanya mengambil kompetensi pedagogic dan kompetensi profesional karena kedua kompetensi ini sangat berpengarug sekali dalam proses belajar mengajar. Menurut Slamet Riyadi kompetensi pedagogik merupakan kemampuan yang harus dimiliki guru berkenaan dengan karakteristik peserta didik dilihat dari berbagai aspek fisik, sosial, kultural, emosional, dan intelektual. ${ }^{10}$ Yang mana kompetensi pedagogic merupakan kompetensi utama bagi seorang pendidik. Dalam mendidik, seorang guru harus menguasai karakteristik peserta didik sehingga proses pendidikan yang dilakukan tidak mengalami hambatan dalam berkomunikasi. Kompetensi pedagogic juga merupakan kompetensi karakter seorang guru. Kompetensi profesioanal merupakan kemampuan guru dalam penguasaan materi pelajaran secara luas dan mendalam yang memungkinkan membimbing peserta didik memenuhi standard kompetensi yang ditetapkan. Menurut Cut Fitriani kompetensi profesional merupakan seperangkat kemampuan yang harus dimiliki oleh seorang guru agara dapat melaksanakan tuga mengajarnya dengan berhasil. Komptensi profesional mencakup penguasaan materi pembelajaran yang terdiri atas penguasaan bahan yang harus diajarkan, penguasaan dan penghayatan atas landasan kependidikan, dan penguasaan proses kependidikan, keguruan dan pembelajaran siswa. Jadi kompetensi profesional merupakan kompetensi yang berhubungan dengan bidang akademik. ${ }^{11}$

Untuk mencapai pembentukan guru-guru yang profesional fungsi dan peran pendidikan sangatlah menentukan, sehingga profesionalitas seorang guru sangatlah dibutuhkan. Undang-undang No 20 Tahun 2003 tentang sistem Pendidikan Nasioanal,

\footnotetext{
${ }^{9}$ Puspa Dianti, “Integrasi Pendidikan Karakter Dalam Pembelajaran Pendidikan Kewarganegaraan Untuk Mengembangkan Karakter Siswa", JPIS Jurnal Pendidikan Ilmu Sosial 23 (1), 2014, hal 58-68. DOI: https://doi.org/10.17509/jpis.v23i1.2062

10 Slamet Riyadin, "Kebijakan pengembangan Profesionalisme Guru PNS", Jurnal Kebijakan Dan Manajemen Publik 4 (2), 2016, hal 219-234. DOI : http://doi.org/10.21070/jkmp.v4i2.697

11 Cut Fitriani, dkk., "Kompetensi Profesional Guru dalam Pengelolahan Pembelajaran di MTS Muhammadiyah Banda Aceh”, Jurnal Adiminatrasi Pendidikan 5 (2), 2017, hal 88-95.
} 
e-ISSN : 2621-4105

Undang-Undang No 14 Tahun 2005 tentang Guru dan Dosen, dan Undang - Undang No 32 Tahun 2013 tentang Standar Nasional Pendidikan, serta Permendikbud No 37 Tahun 2017 tentang Sertifikasi Guru dalam Jabatan, merupakan langkah dan strategi pemerintah Indonesia untuk mendapatkan guru yang profesional.

Berkaitan dengan hal di atas dapat dikatakan bahwa profesionalisme guru sangat penting, karena itu akan berkaitan dengan kualitas pendidikan, kualitas pendidikan berkaitan dengan kualitas bangsa, kualitas banga berkaitan dengan produktifitas bangsa. Semakin bagus profesionalime guru, semakin baguslah pendidikan, semakin bagus pendidikan, semakin bagus kualitas bangsa.

Namun pada kenyataan yang ada dilapangan guru banyak ditemukan kendala dalam guru ini meningkatkan profesionalisme nya seperti, ukurangnya pembiyaan, motivasi dan pengawasan dari supervisi seklah serta kurangnya kemauan dan kesadaran. Sering kali juga ditemukan guru tidak memiliki profesional yang seharusnya dimiliki untuk menjalankan tugas-tugas dan tanggung jawabnya dalam pendidikan. Di kec. Singingi salah satunya daerah yang kebanyakan guru nya mengajar tidak sesuai dengan bidang yang diampunya, seperti pada mata pelejaran PPKn guru yang mengajar di SMPN Kec. Singingi ini banyak yang tidak daru jurusan PPKn, hal ini menyebabkan kurangnya profesionalisme guru karena guru mengajar itu hanya berpatokan kepada penyelesaian tugas saja. Sehingga tidak karang tujuan dari pembelajaran tidak tercapai karena tidak efektifnya saat guru mengajar dikelas. Hal ini menyebabkan mutu pendidikan sulit untuk meningkat. Oleh karena itu diperlukan, adanya kerja sama antara lembaga pendidikan, supervisi sekolah, dan guru serta kesadaran dalam diri seorang guru tersebut untuk mrngembangkan profesionalismenya.

Hasil analisis data menunjukkan bahwa kompetensi yang dimiliki oleh guru PPKn di Kecamatan Singigi belum sepenuhnya menguasai kompetensi pedagogik dan kompetensi profesional tersebut. Terkait kompetensi pedagogic guru PPKn di SMPN kecamatan Singingi pada umumnya dalam memahami karakterisik peserta didik itu sudah mampu. Namun dalam mengauasai teori belajar dan prinsip-prinsip pembelajaran, ataupun mengembangkan kurikulum terkait dengan mata pelajaran masih belum maksimal, dan juga dalam memanfaatkan teknologi informasi dan komunikasi untuk kepentingan pembelajaran, disini belum dapat dikatakan mampu dikarena Guru yang 
e-ISSN : 2621-4105

mengajar pelajaran PPKn di SMPN Kecamatan Singingi ini banyak yang bukan dari bidang PPKn itu sendiri, seperti yang mengajar itu ada daru guru Biologi, bahasa inggris bahkan ada juga yang dari besiknya Matematika.

Mengenai kompetensi profesional, guru PPKn di SMPN kecamatan Singingi dalam kemampuan untuk menguasi materi, struktur,konsep, dan pola pikir keilmuanyang mendukung mata pelajaran PPKn , itu dapat dikatakan belum sepenuhnya mampu. Mungkin ini disebakan Guru yang mengajar pelajaran PPKn di SMPN Kecamatan Singingi ini banyak yang bukan dari budang PPKn itu sendiri, seperti yang mengajar itu ada daru guru Biologi, bahasa inggris bahkan ada juga yang dari besiknya Matematika. Padahal disini guru dituntut dapat menguasai standar kompetensi dan kompetensi dasar mata pelajaran yang diampu kompetensi dan kompetensi dasar mata pelajaran yang diampu secara kreatif, mengembangkan keprofesionalan secara berkelanjutan, memanfaatkan teknologi informasi dan komunikasi untuk mengembangkan diri.

Uapaya pengembangan profesionalisme guru PPKn di SMPN kecamatan Singingi dalam proses pembalajaran dilakukan oleh tiga pihak yaitu Dinas Pendidikan, Pemuda, dan Olahraga Kabupaten Kuantan Singingi,yaitu dengan mengadakan seminar dan workshop. Adapun upaya pengembangan profesonalisme guru PPKn yang dilakukan oleh kepala sekolah yaitu dengan mengadakan rapat sekolah, mengadakan workshop, mengadakan pengawasan (supervisi), memberikan penghargaan (reward) untuk guruguru yang berprestasi, mendorong guru-guru untuk membuat karya tulis ilmiah (KTI) seperti modul dan penelitian tindakan kelas (PTK), dan mendorong guru untuk studi lanjut dengan memberikan motivasi dan bantuan finansial. Guru PPKn dalam mengembangkan profesionalismenya yaitu aktif mencari informasi dan mengikuti kegiatan workshop maupun seminar baik yang diadakan oleh Dinas Dikpora maupun oleh lembaga lainnya, aktif dalam forum Musyawarah Guru Mata Pelajaran (MGMP) Guru SMPN Kecamatan Singingi, mengikuti program sertifikasi guru, dtudi lanjut, dan belajar dari berbagai media seperti media cetak dan internet.

Dalam upaya pengembangan profesionalisme guru PPKn dalam proses pembelajaran di SMPN Kecamatan Singingi terdapat kendala-kenadala yang menghambat dalam guru mengembangkan profesionalismenya yaitu tentunya kendala internal dan kendala eksternal. Kendala internal berupa banyaknya pekerjaan guru yang 
e-ISSN : 2621-4105

harus dikerjakan dan juga kendala dari guru itu sendiri yang memang terkadang tidak mau keluar dari zona nyamannya sendiri sehingga dalam mengikuti segala macam pelatihanpelatihan kebanyakan guru itu malas dalam mengikuti nya. Kendala eksternal dapat dilihat dari kurangnya saran prasarana yang mendukung upaya dalam pengembangan profesionalisme guru dalam proses pembelajaran. Adapun terbentur pada terbatasnya anggaran untuk mengadakan kegiatan pengembangan profesionalime guru dan kurang aktifnya guru dalam forum MGMP ini mungkin dikarenakan kebanyakan guru yang mengajar mata pelajaraan ini tidak berasal dari guru PPKn itu sendiri mungkin dikarenakan mereka juga pergi MGMP pada mata pelajaran nya sesuai dengan besiknya dan akhirnya terabaikan untuk aktif dalam forum MGMP PPKn. Selain itu juga terkendala dengan tempat pelatihan atau MGMP yang mungkin jauh dari sekolah-sekolah dan juga kondisi jalan yang terdang guru malas keluar dari daerahnya. Karena medan yang ditempun cukup sulit untuk dilewatu apalagi ketika hari hujan.

Adapun upaya untuk megatasi kendala-kendala yang menghambat upaya pengembangan profesionalisme guru yaitu terkait pekerjaan guru yang terlalu banyak bisa diatasi dengan membagi waktu sebaik mungkin dan tidak menunda-nunda pekerjaan. Selain itu juga kepala sekolah maupun Dinas Pendidikan, Pemuda, dan Olahraga bisa mengadakan kegiatan guru di waktu tidak banyak pekerjaan, misalnya di waktu jeda atau awal tahun pembelajaran. Terkait kurangnya sarana prasarana, guru bisa mengajukan permohonan kepada sekolah dan memanfaatkan sarana prasarana syang ada semaksimal mungkin. Selain itu kepala sekolah dan dinas bisa meningkatkan anggaran setiap tahunnya, selain itu dinas bisa melakukan workshop maupun seminar melalui MGMP secara berkal. Hal tersebut bisa meminimalisir anggaran. Selanjutnya terkait kurang aktifnya guru dalam forum MGMP, bisa diatasi dengan menyusun jadwal pertemuan yang disepakati oleh guru bersama, dan supaya jadwla juga tidak bentrok dengan MGMP guru yang lainnya dikarenak kenyaka guru disini banyak berasal dari guru mata pelajaran lain dan untuk kepala sekolah seharusnya dapat mencari guru yang memang benar bersal dari pendidikan kewarganegaraan, karena itu mungkin akan bisa mengatasi permasalah kurang aktifnya guru dalam mengikjuti MGMP itu sendiri. Karena dalam mengembangkan profesionalnya dalam mata pelajaran PPKn ini bukan hnya melepas tanggung jawabnya saja tetapi memang benara harus dilakukan oleh setiap guru tersebut 
e-ISSN : 2621-4105

dalam mengembangkan profesionalnya tersebut . Dinas juga bisa memberikan uang stimulan untuk mengaktifkan forum tersebut.

\section{E. PENUTUP}

Berdasarkan pembahasan mengenai upaya dalam mengembangkan profesionalisme guru PPKn di SMPN Kecamatan Singingi dalam proses pembelajaran, maka dapat diambil simpulan bahwa 1) upaya pengembangan profesionalisme guru dalam proses pembelajaran telah dilakukan oleh tiga pihak yaitu dinas pendidikan, kepala sekolah, serta guru mata pelajaran PPKn itu sendiri. Upaya dalam pengembangan profesionalisme guru dalam pembelajaran yang dilakukan oleh Dinas pendidikan, Pemuda, dan Olahraga yaitu mengadakan Workshop, seminar, dan pelatihan-pelatihan. Upaya yang dilakukan oleh kepala sekolah, workshop, supervisi (pengawasan), melaksanakan IHT memberikan penghargaan (reward), mendorong untuk membuat karya ilmiah dan studi lanjut. Upaya yang dilakukan oleh guru mata pelajaran PPKn di Kecamatan Singingi yaitu dengan mengikuti kegiatan workshop dan seminar, aktif dalam forum MGMP, mengikuti program sertifikasi, studi lanjut dan belajar dari berbagai media. 2) kendala-kendala yang menghambat upaya pengembangan profesionalisme guru adalah banyaknya pekerjaan yang harus dilakukan oleh guru, dan juga dari diri guru itu sendiri yang tidak mau keluar dari zona nyamannya, sedangkan kendala dari luar diri guru berupa kurangnya sarana prasarana, keterbatasan anggaran, dan kurang aktifnya guru dalam forum MGMP yang diakibatkan kondisi sekolah yang cukup jauh dari lokasi dari pusat kegiatan, dan ada beberapa sekolah yang mungkin jalannya yang kurang baik. Upaya mengatasi kendala yang menghambat upaya pengembangan profesionalisme guru dapat dilaukan dengan cara (1) membagi waktu sebaik mungkin, tidkak menunda-nunda pekerjaan dan mau untuk keluar dari zona nyamannya, kepala sekolah dan Dinas Dikpora bisa mengadakan kegiatan di waktu guru tidak terlalu bnaya pekerjaan. (2) mengajukan permohonan kepada kepala sekolah, memanfaatkan saran prasarana yang ada semaksimal mungkin dan kepala sekolah dan dinas berusaha untuk memenuhisarana prasarana yang ada semaksimal mungkin dan kepala sekolah dan dinas untuk memenuhi sarana prasarana yang belum tersedia. (3) meningkatkan anggran setiap tahunnya dan dinas bisa melakukan workshop maupun seminar melalui MGMP secara berkala. (4) menyusun 
e-ISSN : 2621-4105

jadwal pertemuan dan memberikan uang stimulan untuk membuat guru lebih bersemangat.

\section{DAFTARA PUSTAKA}

\section{Buku}

Creswel, J, W. (2010), “Reseach Design : Pendekatan Kualitatif, Kuantitatif, dan Mixed”, Yogyakarta: PT Pustaka Pelajar.

H. B. Sutopo, (2002), "Pengantar Penelitian Kualitatif. Surakarta : Universitas Sebelas Maret Press.

Sugiyono Sugiyono, (2010), “Metodologi Penelitian Pendidikan Kualitatif, Pendekatan Kuantitatif, Kualitatif, dan R\&D”, Bandung: Alfabeta.

\section{Jurnal}

Cut Fitriani, dkk., "Kompetensi Profesional Guru dalam Pengelolahan Pembelajaran di MTS Muhammadiyah Banda Aceh", Jurnal Adiminatrasi Pendidikan 5 (2), 2017.

Fadlillah Hamni Nasution, "Urgensi Profesionalisme Guru di Pendidikan Sekolah Dasar”, Jurnal Ar Riayah : Jurnal Pendidikan Dasar 1 (1), 2017.

DOI: http://dx.doi.org/10.29240/jpd.v1i1.218

Heri Hidayat, Heny Mulyani, Sri Devi Nurhasanah, Wilma Khairunnisa, Zakitush Sholihah, "Peranan Teknologi Dan Media Pembelajaran Bagi Siswa Sekolah Dasar Di Dalam Pembelajaran Pendidikan Kewarganegaraan”, Jurnal Pendidikan Kewarganegaraan 8 (2) 2020. DOI: http://dx.doi.org/10.23887/jpku.v8i2.24759

Puspa Dianti, "Integrasi Pendidikan Karakter Dalam Pembelajaran Pendidikan Kewarganegaraan Untuk Mengembangkan Karakter Siswa" JPIS, Jurnal $\begin{array}{lllll}\text { Pendidikan Ilmu } & \text { Sosial } & 23 & \text { (1), } & \end{array}$ DOI: https://doi.org/10.17509/jpis.v23i1.2062

Slamet Riyadin, "Kebijakan pengembangan Profesionalisme Guru PNS", Jurnal Kebijakan Dan Manajemen Publik 4 (2), 2016. DOI : http://doi.org/10.21070/jkmp.v4i2.697

Sri Haryati, "Konstruksi Isu Aktual Bidang Ketahanan Nasional Untuk Pengembangan Isi Pendidikan Kewarganegaraan Persekolahan”, Jurnal Ketahanan Nasional 24 (3), 2018. https://doi.org/10.22146/jkn.35490

Sri Wahyuni Tanshzil, "Model Pembinaan Pendidikan Karakter Pada Lingkungan Pondok Pesantren Dalam Membangun Kemandirian Dan Disiplin Santri (Sebuah kajian pengembangan Pendidikan Kewarganegaraan)" Jurnal Pendidikan Penelitian 12 (2), 2012.

\section{Peraturan Perundang-Undangan}

Peraturan Pemerintan Nomor 74 Tahun 2008. Tentang Guru.

Undang-Undang Nomor 20 Tahun 2003. Tentang Sistem Pendidikan Nasional.

Undang-Undang Nomor 14 Tahun 2005. Tentang Guru dan Dosen.

Undang-Undang Nomor 18 Tahun 2007. Tentanng Sertifikasi Guru dalam Jabatan. 
e-ISSN : 2621-4105

Undang-Undang Nomor 16 Tahun 2007. Tentang Standar Kualifikasi Akademik dan Kompetensi Guru. 